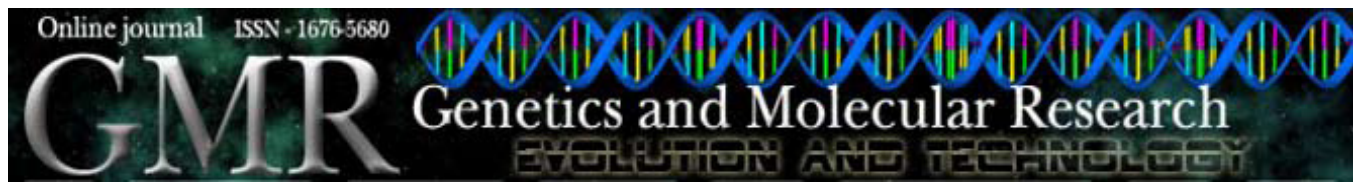

\title{
Genotoxicity testing of Ambelania occidentalis (Apocynaceae) leaf extract in vivo
}

\author{
L.S. Castro ${ }^{1}$, F.F. Perazzo $^{2}$ and E.L. Maistro ${ }^{1}$ \\ ${ }^{1}$ Departamento de Fonoaudiologia, \\ Faculdade de Filosofia e Ciências, \\ Universidade Estadual Paulista, Marília, SP, Brasil \\ ${ }^{2}$ Laboratório de Pesquisa em Fármacos, \\ Universidade Federal do Amapá, Macapá, AM, Brasil \\ Corresponding author: E.L. Maistro \\ E-mail: edson.maistro@marilia.unesp.br
}

Genet. Mol. Res. 8 (2): 440-447 (2009)

Received February 20, 2009

Accepted March 9, 2009

Published April 22, 2009

\begin{abstract}
Ambelania occidentalis is routinely used in folk medicine for treating gastrointestinal disorders, even though there have been no safety trials. We evaluated the genotoxic potential of hydro-alcoholic extracts of this plant in mice; induced DNA damage was assessed in peripheral blood leukocytes and micronucleus induction was assessed in polychromatic erythrocytes from bone marrow. The extract was administered by an oral route at single doses of 1000, 1500 and $2000 \mathrm{mg} /$ $\mathrm{kg}$ body weight. N-nitroso-N-ethylurea was used as a positive control. The comet assay was performed on peripheral blood leukocytes at 4 and $24 \mathrm{~h}$ after treatment, and the micronucleus test was carried out on bone marrow cells collected at 24 and $48 \mathrm{~h}$ after treatment. The ratio of polychromatic/normochromatic erythrocytes was scored for cytotoxicity assessment. No increase in the number of micronucleated polychromatic erythrocytes from bone marrow or in leukocyte DNA damage was observed. The hydro-alcoholic extracts of $A$. occidentalis had no mutagenic or cytotoxic effects in the mouse cells.
\end{abstract}

Key words: Ambelania occidentalis; Comet assay; Micronucleus test; Single-cell gel electrophoresis; Mutagenicity assay 


\section{INTRODUCTION}

The use of medicinal plants in therapeutics or as dietary supplements goes back beyond recorded history, but has increased substantially in the last decades (Woods, 1999; WHO, 2002). The popularity of herbal medicines is connected with their easy access, therapeutic efficacy, relatively low cost, and assumed absence of toxic side effects. Widespread public opinion is that being a natural product, herbal medicines are harmless and free from adverse effects, and it is believed that even if the expected medical effect is not achieved, their consumption is not dangerous. However, the safety of their use has recently been questioned due to the reports of illness and fatalities (Stewart et al., 1999; Ernst, 2002; Veiga-Junior et al., 2005). Considering the complexity of herbals in general and their inherent biological variation, it is now necessary to evaluate their safety, efficacy and quality (WHO, 2002). Thus, an assessment of their mutagenic and cytotoxic potential is necessary to ensure the relatively safe use of plant-derived medicines.

The Apocynaceae family has been studied extensively over the years with regard to the cytotoxicity of its secondary metabolites, mainly alkaloids. The first well-known plants of this family were Rauwolfia serpentine, containing reserpine, used for hypertension, and Catharanteus roseus, containing vincristine and vimblastine, used in the treatment of uterus and breast cancer (Ram and Kumari, 2001). Also, another genus, Tabernaemontana, has been studied as a potential herbal medicine against Leishmania (Estevez et al., 2007), Chagas disease and malaria (Ndjakou et al., 2007)

Ambelania occidentalis belongs to the Apocynaceae family. This botanical family includes 4555 species, distributed in 415 genera. In Brazil, there are 376 species from 41 genera. There is no available detailed phytochemical screen of $A$. occidentalis leaf extract, which is under study by our group. Thus, the Apocynaceae family has shown over the decades high cytotoxic effects because of alkaloids in its composition, where they are common secondary metabolites (Endress and Bruyns, 2000). Therefore, this study was undertaken to determine the in vivo genotoxic/mutagenic effect, if any, of acute administration of $A$. occidentalis leaf extract in mice, using the comet and micronucleus assays.

\section{MATERIAL AND METHODS}

\section{Plant material}

Dried leaves of $A$. occidentalis ( $300 \mathrm{~g}$ ) were submitted to dynamic maceration with ethanol $(2000 \mathrm{~mL}, 99.0 \%)$ for $4 \mathrm{~h}$. The extract of the macerated leaves was filtered and the resulting filtrate concentrated under reduced pressure, yielding $23.46 \mathrm{~g}(7.82 \%)$ of crude hydro-alcoholic extract.

\section{Chemicals}

N-nitroso-N-ethylurea (ENU, CAS No. 759-73-9) was used as the DNA damaging agent in the comet and chromosome aberration assays. It was dissolved in phosphate buffer, $\mathrm{pH}$ 6. The other main chemicals were obtained from the following suppliers: normal melting point agarose (Cat. No. 15510-019; Invitrogen); low melting point agarose (Cat. No. 15517- 
014; Invitrogen); $N$-lauroyl sarcosine sodium salt (L-5125; Sigma), and ethylenediaminetetraacetic acid (Merck).

\section{Animals and dosing}

Experiments were carried out on 12-week-old male Swiss albino mice (Mus musculus), weighing 25-30 g. The animals were acquired from the animal house of the Universidade Estadual Paulista (UNESP), Botucatu, São Paulo State, Brazil, and kept in polyethylene boxes (N $=11)$, in a climate-controlled environment $\left(25 \pm 4^{\circ} \mathrm{C}, 55 \pm 5 \%\right.$ relative humidity) with a 12 -h light/dark cycle (7:00 am to 7:00 pm). Food (NUVILAB CR1 - NUVITAL) and water were available ad libitum. The mice were divided into experimental groups of 11 animals. An extract of Ambelania occidentalis leaves was administered in a single dose of $0.5 \mathrm{~mL}$ by gavage, at concentrations of 1000,1500 , and $2000 \mathrm{mg} / \mathrm{kg}$ body weight, chosen on the basis of our acute toxicity studies in mice, which was higher than $2000 \mathrm{mg} / \mathrm{kg}$. The negative control group received distilled water. The positive control group received an intraperitoneal injection of ENU at $50 \mathrm{mg} /$ $\mathrm{kg}$. The animals used in this study were sacrificed by cervical dislocation. The Animal Bioethics Committee of the UNESP, Botucatu, Brazil, approved the present study on September 28, 2006 (protocol number 47/06), in accordance with Brazilian regulations on animal care.

\section{Micronucleus assay}

The assay was carried out following standard protocols as recommended by Schmid (1975) and Krishna and Hayashi (2000). Ten mice were used per group (five for each gender) in the test. Five animals of each group were sacrificed $24 \mathrm{~h}$ after the treatment and the other five $48 \mathrm{~h}$ after the treatment. This protocol was chosen considering the observation that the time course of micronucleus production in polychromatic erythrocytes can be different for each of the chemicals studied (Salamone et al., 1980). The bone marrow from both femurs was flushed out using $2 \mathrm{~mL}$ saline $(0.9 \% \mathrm{NaCl})$ and centrifuged for $7 \mathrm{~min}$. The supernatant was discarded and smears were made on slides. The slides were coded for a "blind" analysis, fixed with methanol and stained with Giemsa. For the analysis of the micronucleated cells, 2000 polychromatic erythrocytes (PCE) per animal were scored to determine the mutagenic property of the extract. To detect possible cytotoxic effects, the PCE:NCE (normochromatic erythrocytes) ratio in 200 erythrocytes/animal was calculated (Gollapudi and McFadden, 1995). The cells were blindly scored using a light microscope at 1000X magnification. The mean number of micronucleated PCE in individual mice was used as the experimental unit, with variability (standard deviation) based on differences among animals within the same group.

\section{Comet assay}

The comet assay (single-cell gel electrophoresis, SCGE) was carried out by the method described by Speit and Hartmann (1999), which is based on the original work of Singh et al. (1988) and includes modifications introduced by Klaude et al. (1996) as well as additional modifications. Peripheral blood samples were obtained from six Swiss mice from each group at 4 and $24 \mathrm{~h}$ after treatment. An aliquot was removed from the peripheral blood cell suspension to determine cell viability. Cell counting was performed using a hemocytometer. Cell viability was 
determined by Trypan blue dye exclusion. The number of Trypan blue-negative cells was considered the number of viable cells and was greater than $90 \%$. A $10-\mu \mathrm{L}$ aliquot of cells from each animal was mixed with $120 \mu \mathrm{L} 0.5 \%$ low melting point agarose at $37^{\circ} \mathrm{C}$, and rapidly spread onto two microscope slides per animal, pre-coated with $1.5 \%$ normal melting point agarose. The slides were coverslipped and allowed to gel at $4{ }^{\circ} \mathrm{C}$ for $20 \mathrm{~min}$. The coverslips were gently removed and the slides were then immersed in cold, freshly prepared lysing solution consisting of $89 \mathrm{~mL}$ of a stock solution ( $2.5 \mathrm{M} \mathrm{NaCl}, 100 \mathrm{mM}$ EDTA, $10 \mathrm{mM}$ Tris, $\mathrm{pH}$ set to 10.0 with $\sim 8 \mathrm{~g}$ solid $\mathrm{NaOH}$, $890 \mathrm{~mL}$ distilled water and 1\% sodium lauryl sarcosine), plus $1 \mathrm{~mL}$ Triton X-100 (Merck) and $10 \mathrm{~mL}$ dimethylsulfoxide (Merck). The slides, which were protected from light, were allowed to stand at $4^{\circ} \mathrm{C}$ for $1 \mathrm{~h}$ and then placed in the gel box, positioned at the anode end, and left in a high $\mathrm{pH}(>13)$ electrophoresis buffer $(300 \mathrm{mM} \mathrm{NaOH}-1 \mathrm{mM}$ EDTA, prepared from a stock solution of $10 \mathrm{~N} \mathrm{NaOH}$ and $200 \mathrm{mM}, \mathrm{pH} 10.0$, EDTA) at $4^{\circ} \mathrm{C}$ for $20 \mathrm{~min}$ prior to electrophoresis, to allow DNA unwinding. The electrophoresis run was carried out in an ice bath $\left(4^{\circ} \mathrm{C}\right)$ for $20 \mathrm{~min}$ at 300 $\mathrm{mA}$ and $25 \mathrm{~V}(0.722 \mathrm{~V} / \mathrm{cm})$. The slides were then submerged in a neutralization buffer $(0.4 \mathrm{M}$ Tris-HCl, $\mathrm{pH}$ 7.5) for $15 \mathrm{~min}$, dried at room temperature and fixed in $100 \%$ ethanol for $10 \mathrm{~min}$. The slides were dried and stored overnight or longer, before staining. For the staining process, the slides were briefly rinsed in distilled water, covered with $30 \mu \mathrm{L} 1 \mathrm{X}$ ethidium bromide-staining solution prepared from a $10 \mathrm{X}$ stock $(200 \mu \mathrm{g} / \mathrm{mL})$ and coverslipped. The material was evaluated immediately at $400 \mathrm{X}$ magnification, using a fluorescence microscope (Olympus BX 50) with a 515-560-nm excitation filter and a 590-nm barrier filter.

The extent and distribution of DNA damage indicated by the SCGE assay were evaluated by examining at least 100 randomly selected and non-overlapping cells on the slides (50 cells per slide), per animal. These cells were scored visually, according to tail size, into four classes, as follows: class 0 : no tail; class 1: tail shorter than the diameter of the head (nucleus); class 2: tail length 1 to 2 times the diameter of the head, and class 3 : tail longer than 2 times the diameter of the head. Comets with no heads and images with nearly all DNA in the tail, or with a very wide tail, were excluded from the evaluation because they probably represent dead cells (Hartmann and Speit, 1997). The total score for 100 comets was obtained by multiplying the number of cells in each class by the damage class, ranging from 0 (all undamaged) to 300 (all maximally damaged).

\section{Statistical analysis}

After verifying if the data were normally distributed, the data obtained on micronucleus and SCGE assays were submitted to one-way analysis of variance (ANOVA) followed by the Tukey test (Sokal and Rohlf, 1995) comparing all groups with the negative control group. GraphPad Instat ${ }^{\circledR}$ software (version 3.01) was used. The results were considered to be statistically significant at $\mathrm{P}<0.05$.

\section{RESULTS AND DISCUSSION}

From a phytomedicinal point of view, the evaluation of genotoxicity is of particular importance due to the fact that genotoxic effects of chemicals or complex mixtures may be crucially important at the population level. Of the variety of in vivo assays used to detect genotoxic chemicals, the most common is the in vivo rodent erythrocyte micronucleated assay. 
This assay has been used routinely for decades and has typically been used to detect damage to the chromosomes or the mitotic apparatus. Substances that cause cytogenetic damage may give rise to cells with micronuclei, which consist of lagging chromosome fragments (a result of clastogenic activity) or whole chromosomes (due to aneugenic activity) (MacGregor et al., 1990; Heddle et al., 1991; Hayashi et al., 1994).

The micronucleated data for $A$. occidentalis extract are summarized in Table 1. All results regarding micronucleated cells from extract-treated groups were not statistically different from the negative control. Also, no significant difference between the test groups was observed.

Table 1. Number of micronucleated polychromatic erythrocytes (MNPCE) observed in the bone marrow cells of male (M) Swiss mice treated with Ambelania occidentalis extract, and respective controls.

\begin{tabular}{|c|c|c|c|c|c|c|c|c|}
\hline \multirow[t]{2}{*}{ Treatment } & \multirow{2}{*}{$\begin{array}{l}\text { Times of cell } \\
\text { collection }\end{array}$} & \multicolumn{5}{|c|}{ Number of MNPCE per animal } & \multirow{2}{*}{$\begin{array}{c}\text { MNPCE } \\
(\text { mean } \pm \text { SD) }\end{array}$} & \multirow{2}{*}{$\begin{array}{c}\mathrm{PCE} / \mathrm{NCE} \\
(\text { mean } \pm \mathrm{SD})\end{array}$} \\
\hline & & $\mathrm{M}_{1}$ & $\mathrm{M}_{2}$ & $\mathrm{M}_{3}$ & $\mathrm{M}_{4}$ & $\mathrm{M}_{5}$ & & \\
\hline $\begin{array}{l}\text { Negative control } \\
\text { (water) }\end{array}$ & $\begin{array}{l}24 \mathrm{~h} \\
48 \mathrm{~h}\end{array}$ & $\begin{array}{l}1 \\
1\end{array}$ & $\begin{array}{l}3 \\
1\end{array}$ & $\begin{array}{l}2 \\
0\end{array}$ & $\begin{array}{l}2 \\
0\end{array}$ & $\begin{array}{l}2 \\
2\end{array}$ & $\begin{array}{l}2.0 \pm 0.70 \\
0.8 \pm 0.83\end{array}$ & $\begin{array}{l}0.84 \pm 0.11 \\
0.84 \pm 0.12\end{array}$ \\
\hline $\begin{array}{l}\text { A. occidentalis extract } \\
(1000 \mathrm{mg} / \mathrm{kg})\end{array}$ & $\begin{array}{l}24 \mathrm{~h} \\
48 \mathrm{~h}\end{array}$ & $\begin{array}{l}0 \\
1\end{array}$ & $\begin{array}{l}1 \\
0\end{array}$ & $\begin{array}{l}1 \\
1\end{array}$ & $\begin{array}{l}1 \\
1\end{array}$ & $\begin{array}{l}0 \\
1\end{array}$ & $\begin{array}{l}0.6 \pm 0.54 \\
0.8 \pm 0.44\end{array}$ & $\begin{array}{l}0.97 \pm 0.11 \\
0.88 \pm 0.05\end{array}$ \\
\hline $\begin{array}{l}\text { A. occidentalis extract } \\
(1500 \mathrm{mg} / \mathrm{kg})\end{array}$ & $\begin{array}{l}24 \mathrm{~h} \\
48 \mathrm{~h}\end{array}$ & $\begin{array}{l}1 \\
1\end{array}$ & $\begin{array}{l}0 \\
0\end{array}$ & $\begin{array}{l}1 \\
1\end{array}$ & $\begin{array}{l}2 \\
1\end{array}$ & $\begin{array}{l}1 \\
1\end{array}$ & $\begin{array}{l}1.0 \pm 0.70 \\
0.8 \pm 0.44\end{array}$ & $\begin{array}{l}0.83 \pm 0.10 \\
0.90 \pm 0.03\end{array}$ \\
\hline $\begin{array}{l}\text { A. occidentalis extract } \\
(2000 \mathrm{mg} / \mathrm{kg})\end{array}$ & $\begin{array}{l}24 \mathrm{~h} \\
48 \mathrm{~h}\end{array}$ & $\begin{array}{l}2 \\
0\end{array}$ & $\begin{array}{l}1 \\
1\end{array}$ & $\begin{array}{l}1 \\
0\end{array}$ & $\begin{array}{l}1 \\
1\end{array}$ & $\begin{array}{l}2 \\
1\end{array}$ & $\begin{array}{l}1.4 \pm 0.54 \\
0.6 \pm 0.54\end{array}$ & $\begin{array}{l}0.87 \pm 0.06 \\
0.84 \pm 0.07\end{array}$ \\
\hline $\begin{array}{l}\text { N-nitroso-N-ethylurea } \\
(50 \mathrm{mg} / \mathrm{kg})\end{array}$ & $\begin{array}{l}24 \mathrm{~h} \\
48 \mathrm{~h}\end{array}$ & $\begin{array}{l}13 \\
11\end{array}$ & $\begin{array}{l}14 \\
14\end{array}$ & $\begin{array}{l}14 \\
12\end{array}$ & $\begin{array}{r}13 \\
9\end{array}$ & $\begin{array}{l}14 \\
12\end{array}$ & $\begin{array}{l}13.6 \pm 0.54^{\mathrm{a}} \\
11.6 \pm 1.81^{\mathrm{b}}\end{array}$ & $\begin{array}{l}0.91 \pm 0.05 \\
0.84 \pm 0.06\end{array}$ \\
\hline
\end{tabular}

For each period (24 and 48 h), 2000 cells were analyzed. SD = standard deviation; NCE = normochromatic

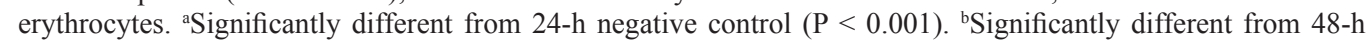
negative control $(\mathrm{P}<0.001)$.

An evaluation in the bone marrow cells of the percentage of PCE among total erythrocytes was included to provide an assessment of the rate of erythropoiesis and thus a measure of cytotoxicity. The estimated ratio of PCE:NCE in bone marrow preparations showed no statistically significant alterations in hematopoiesis as a result of extract treatment, indicating no cytotoxic effects.

The SCGE assay, commonly called the comet assay, is an assay for genotoxicity that is gaining widespread use. This assay has the advantages of requiring a small number of cells per sample, being amenable to almost all cell types whether actively dividing or quiescent, and being relatively inexpensive, since only basic equipment is required (Tice et al., 2000; Hartmann et al., 2001, 2003; Brendler-Schwaab et al., 2005). In the comet assay, cells are embedded on agarose gel on a glass slide, lysed to break cell and nuclear membranes, and exposed to an alkaline solution to yield single-stranded DNA from released double-stranded DNA. Following electrophoresis, the sample is stained with a DNA-binding dye and viewed under a microscope. Short strands of DNA generated from DNA strand breaks and/or alkaline labile sites (depending on $\mathrm{pH}$ of the electrophoresis solution) migrate farther than intact DNA during electrophoresis and form the "tail" of the "comet". 
The results of the comet assay in evaluating the $A$. occidentalis extract, namely data on the total number of cells with damage and scores for mice treated with 1000, 1500, and 2000 $\mathrm{mg} / \mathrm{kg}$, besides negative and positive control (50 mg/kg ENU) are presented in Tables 2 and 3.

\begin{tabular}{|c|c|c|c|c|c|c|c|}
\hline \multirow[t]{2}{*}{ Treatment } & \multirow[t]{2}{*}{ Animals } & \multirow[t]{2}{*}{ Total $^{1}$} & \multicolumn{3}{|c|}{ Comet class } & \multirow[b]{2}{*}{3} & \multirow[t]{2}{*}{ Score } \\
\hline & & & 0 & 1 & 2 & & \\
\hline \multirow[t]{7}{*}{ Control } & $\mathrm{M}_{1}$ & 1 & 99 & 1 & 0 & 0 & 2 \\
\hline & $\mathrm{M}_{2}$ & 2 & 98 & 2 & 0 & 0 & 2 \\
\hline & $\mathrm{M}_{3}$ & 1 & 99 & 1 & 0 & 0 & 1 \\
\hline & $\mathrm{M}_{4}$ & 4 & 96 & 4 & 0 & 0 & 4 \\
\hline & $\mathrm{M}_{5}^{4}$ & 2 & 98 & 2 & 0 & 0 & 2 \\
\hline & $\mathrm{M}_{6}$ & 3 & 97 & 3 & 0 & 0 & 3 \\
\hline & Mean \pm SD & $2.1 \pm 1.1$ & & & & & $2.3 \pm 1.0$ \\
\hline \multirow{7}{*}{$\begin{array}{l}\text { A. occidentalis extract } \\
(1000 \mathrm{mg} / \mathrm{kg})\end{array}$} & $\mathrm{M}_{1}$ & 1 & 99 & 1 & 0 & 0 & 1 \\
\hline & $\mathrm{M}_{2}$ & 1 & 99 & 1 & 0 & 0 & 1 \\
\hline & $\mathrm{M}_{3}^{2}$ & 9 & 91 & 9 & 0 & 0 & 9 \\
\hline & $\mathrm{M}_{4}$ & 6 & 94 & 6 & 0 & 0 & 6 \\
\hline & $\mathrm{M}_{5}^{4}$ & 2 & 98 & 2 & 0 & 0 & 2 \\
\hline & $\mathrm{M}_{6}$ & 3 & 97 & 3 & 0 & 0 & 3 \\
\hline & Mean \pm SD & $3.6 \pm 3.2$ & & & & & $3.6 \pm 3.2$ \\
\hline \multirow{7}{*}{$\begin{array}{l}\text { A. occidentalis extract } \\
(1500 \mathrm{mg} / \mathrm{kg})\end{array}$} & $\mathrm{M}_{1}$ & 2 & 98 & 2 & 0 & 0 & 2 \\
\hline & $\mathrm{M}_{2}$ & 1 & 99 & 1 & 0 & 0 & 1 \\
\hline & $\mathrm{M}_{3}^{2}$ & 2 & 98 & 2 & 0 & 0 & 2 \\
\hline & $\mathrm{M}_{4}$ & 3 & 97 & 3 & 0 & 0 & 3 \\
\hline & $\mathrm{M}_{5}^{+}$ & 1 & 99 & 1 & 0 & 0 & 1 \\
\hline & $\mathrm{M}_{6}$ & 1 & 99 & 1 & 0 & 0 & 1 \\
\hline & Mean \pm SD & $1.6 \pm 0.8$ & & & & & $1.6 \pm 0.8$ \\
\hline \multirow{7}{*}{$\begin{array}{l}\text { A. occidentalis extract } \\
(2000 \mathrm{mg} / \mathrm{kg})\end{array}$} & $\mathrm{M}_{1}$ & 7 & 93 & 7 & 0 & 0 & 7 \\
\hline & $\mathrm{M}_{2}$ & 3 & 97 & 3 & 0 & 0 & 3 \\
\hline & $\mathrm{M}_{3}^{2}$ & 4 & 96 & 4 & 0 & 0 & 4 \\
\hline & $\mathrm{M}_{4}$ & 4 & 96 & 4 & 0 & 0 & 4 \\
\hline & $\mathrm{M}_{5}^{4}$ & 5 & 95 & 5 & 0 & 0 & 5 \\
\hline & $\mathrm{M}_{6}^{3}$ & 6 & 94 & 6 & 0 & 0 & 6 \\
\hline & Mean \pm SD & $4.8 \pm 1.4$ & & & & & $4.8 \pm 1.4$ \\
\hline \multirow{7}{*}{$\begin{array}{l}\text { N-nitroso-N-ethylurea } \\
(50 \mathrm{mg} / \mathrm{kg})\end{array}$} & $\mathrm{M}_{1}$ & 70 & 30 & 67 & 3 & 0 & 73 \\
\hline & $\mathrm{M}_{2}$ & 75 & 25 & 74 & 1 & 0 & 76 \\
\hline & $\mathrm{M}_{3}^{2}$ & 66 & 34 & 66 & 0 & 0 & 66 \\
\hline & $\mathrm{M}_{4}$ & 76 & 24 & 75 & 1 & 0 & 77 \\
\hline & $\mathrm{M}_{5}^{4}$ & 74 & 26 & 72 & 2 & 0 & 76 \\
\hline & $\mathrm{M}_{6}$ & 75 & 25 & 75 & 0 & 0 & 75 \\
\hline & Mean \pm SD & $72.6 \pm 3.8^{*}$ & & & & & $73.8 \pm 4.0^{*}$ \\
\hline
\end{tabular}

${ }^{1}$ Total number of damaged cells (classes $\left.1+2+3\right)$. * Significantly different from the negative control $(\mathrm{P}<0.001)$.

As expected, N-nitroso-N-ethylurea, the positive control, induced a significant increase in DNA migration in leukocytes $(\mathrm{P}<0.001)$. Despite some increase in damaged cells in animals treated with high doses of the test extract, no statistically significant difference between treated and untreated animals was observed for A. occidentalis extract at all doses tested, in both leukocyte samples $(4 \mathrm{~h}$ and $24 \mathrm{~h})(\mathrm{P}>0.05)$. When cells were exposed to three concentrations of the extract, most of the cells examined on slides were undamaged, few cells showed minor damage (class 1) and very few showed a large amount 


\begin{tabular}{|c|c|c|c|c|c|c|c|}
\hline \multirow[t]{2}{*}{ Treatment } & \multirow[t]{2}{*}{ Animals } & \multirow[t]{2}{*}{ Total $^{1}$} & \multicolumn{4}{|c|}{ Comet class } & \multirow[t]{2}{*}{ Score } \\
\hline & & & 0 & 1 & 2 & 3 & \\
\hline \multirow{7}{*}{ Control } & $M_{1}$ & 3 & 97 & 3 & 0 & 0 & 3 \\
\hline & $\mathrm{M}_{2}$ & 5 & 95 & 5 & 0 & 0 & 5 \\
\hline & $\mathrm{M}_{3}^{2}$ & 3 & 97 & 3 & 0 & 0 & 3 \\
\hline & $\mathrm{M}_{4}$ & 4 & 96 & 4 & 0 & 0 & 4 \\
\hline & $\mathrm{M}_{5}^{4}$ & 4 & 96 & 4 & 0 & 0 & 4 \\
\hline & $M_{6}$ & 5 & 95 & 5 & 0 & 0 & 5 \\
\hline & Mean \pm SD & $4.0 \pm 0.8$ & & & & & $4.0 \pm 0.8$ \\
\hline \multirow{7}{*}{$\begin{array}{l}\text { A. occidentalis extract } \\
(1000 \mathrm{mg} / \mathrm{kg})\end{array}$} & $\mathrm{M}_{1}$ & 10 & 90 & 10 & 0 & 0 & 10 \\
\hline & $\mathrm{M}_{2}$ & 2 & 98 & 2 & 0 & 0 & 2 \\
\hline & $\mathrm{M}_{3}^{2}$ & 1 & 99 & 1 & 0 & 0 & 1 \\
\hline & $\mathrm{M}_{4}$ & 1 & 99 & 1 & 0 & 0 & 1 \\
\hline & $\mathrm{M}_{5}^{4}$ & 5 & 95 & 5 & 0 & 0 & 5 \\
\hline & $M_{6}$ & 11 & 89 & 11 & 0 & 0 & 11 \\
\hline & Mean \pm SD & $5.0 \pm 4.5$ & & & & & $5.0 \pm 4.5$ \\
\hline \multirow{7}{*}{$\begin{array}{l}\text { A. occidentalis extract } \\
(1500 \mathrm{mg} / \mathrm{kg})\end{array}$} & $\mathrm{M}_{1}$ & 3 & 97 & 3 & 0 & 0 & 3 \\
\hline & $\mathrm{M}_{2}$ & 2 & 98 & 2 & 0 & 0 & 2 \\
\hline & $\mathrm{M}_{3}^{2}$ & 1 & 99 & 1 & 0 & 0 & 1 \\
\hline & $\mathrm{M}_{4}$ & 1 & 99 & 1 & 0 & 0 & 1 \\
\hline & $\mathrm{M}_{5}^{4}$ & 2 & 98 & 2 & 0 & 0 & 2 \\
\hline & $M_{6}$ & 1 & 99 & 1 & 0 & 0 & 1 \\
\hline & Mean \pm SD & $1.6 \pm 0.8$ & & & & & $1.6 \pm 0.8$ \\
\hline \multirow{7}{*}{$\begin{array}{l}\text { A. occidentalis extract } \\
(2000 \mathrm{mg} / \mathrm{kg})\end{array}$} & $\mathrm{M}_{1}$ & 1 & 99 & 1 & 0 & 0 & 1 \\
\hline & $\mathrm{M}_{2}$ & 4 & 96 & 4 & 0 & 0 & 4 \\
\hline & $\mathrm{M}_{3}^{2}$ & 4 & 96 & 4 & 0 & 0 & 4 \\
\hline & $\mathrm{M}_{4}$ & 2 & 98 & 2 & 0 & 0 & 2 \\
\hline & $\mathrm{M}_{5}^{4}$ & 5 & 95 & 5 & 0 & 0 & 5 \\
\hline & $\mathrm{M}_{6}$ & 4 & 96 & 4 & 0 & 0 & 4 \\
\hline & Mean \pm SD & $3.3 \pm 1.5$ & & & & & $3.3 \pm 1.5$ \\
\hline \multirow{7}{*}{$\begin{array}{l}\text { N-nitroso-N-ethylurea } \\
(50 \mathrm{mg} / \mathrm{kg})\end{array}$} & $\mathrm{M}_{1}$ & 78 & 22 & 71 & 6 & 1 & 86 \\
\hline & $\mathrm{M}_{2}$ & 77 & 23 & 70 & 7 & 0 & 84 \\
\hline & $\mathrm{M}_{3}^{2}$ & 77 & 23 & 75 & 2 & 0 & 79 \\
\hline & $\mathrm{M}_{4}$ & 63 & 37 & 60 & 3 & 0 & 66 \\
\hline & $\mathrm{M}_{5}^{4}$ & 62 & 38 & 61 & 1 & 0 & 63 \\
\hline & $\mathrm{M}_{6}$ & 69 & 31 & 66 & 3 & 0 & 72 \\
\hline & Mean \pm SD & $71.0 \pm 7.3^{*}$ & & & & & $75.0 \pm 9.5^{*}$ \\
\hline
\end{tabular}

${ }^{1}$ Total number of damaged cells (classes $\left.1+2+3\right)$. $*$ Significantly different from the negative control $(\mathrm{P}<0.001)$.

of damage (classes 2 and 3). Furthermore, there were no significant differences in DNA migration between the three extract concentrations tested and between the two leukocyte time samples, indicating no significant differences in DNA damage before and after the DNA cell repair process. The cell viability for leukocytes was greater than $90 \%$ using Trypan blue staining, confirming the absence of cytotoxicity observed by the PCE:NCE ratio in the micronucleus test.

Thus, under the conditions of the assays employed here, the data obtained in the present study permit us to conclude that acute oral administration of $A$. occidentalis leaf extract in mice, at the doses of 1000,1500 , and $2000 \mathrm{mg} / \mathrm{kg}$, showed no evidence of clastogenicity/genotoxicity (i.e., no increase in micronucleus PCE or DNA damage) or cytotoxicity in vivo. 


\section{ACKNOWLEDGMENTS}

Research supported by the Brazilian agencies CNPq (\#306544/2006-7) and FAPESP Fundação de Amparo à Pesquisa do Estado de São Paulo (\#2006/57514-2). We thank Patrícia C. Martins Mello for technical assistance.

\section{REFERENCES}

Brendler-Schwaab S, Hartmann A, Pfuhler S and Speit G (2005). The in vivo comet assay: use and status in genotoxicity testing. Mutagenesis 20: 245-254.

Endress ME and Bruyns PV (2000). A revised classification of Apocynaceae. Bot. Rev. 66: 1-56.

Ernst E (2002). Toxic heavy metals and undeclared drugs in Asian herbal medicines. Trends Pharmacol. Sci. 23: 136-139.

Estevez Y, Castillo D, Pisango MT, Arevalo J, et al. (2007). Evaluation of the leishmanicidal activity of plants used by Peruvian Chayahuita ethnic group. J. Ethnopharmacol. 114: 254-259.

Gollapudi BB and McFadden LG (1995). Sample size for the estimation of polychromatic to normochromatic erythrocyte ratio in the bone marrow micronucleus test. Mutat. Res. 347: 97-99.

Hartmann A and Speit G (1997). The contribution of cytotoxicity to DNA-effects in the single cell gel test (comet assay). Toxicol. Lett. 90: 183-188.

Hartmann A, Elhajouji A, Kiskinis E, Poetter F, et al. (2001). Use of the alkaline comet assay for industrial genotoxicity screening: comparative investigation with the micronucleus test. Food Chem. Toxicol. 39: 843-858.

Hartmann A, Agurell E, Beevers C, Brendler-Schwaab S, et al. (2003). Recommendations for conducting the in vivo alkaline Comet assay. 4th International Comet Assay Workshop. Mutagenesis 18: 45-51.

Hayashi M, Tice RR, MacGregor JT, Anderson D, et al. (1994). In vivo rodent erythrocyte micronucleus assay. Mutat. Res. 312: 293-304.

Heddle JA, Cimino MC, Hayashi M, Romagna F, et al. (1991). Micronuclei as an index of cytogenetic damage: past, present, and future. Environ. Mol. Mutagen. 18: 277-291.

Klaude M, Eriksson S, Nygren J and Ahnstrom G (1996). The comet assay: mechanisms and technical considerations. Mutat. Res. 363: 89-96.

Krishna G and Hayashi M (2000). In vivo rodent micronucleus assay: protocol, conduct and data interpretation. Mutat. Res. 455: 155-166.

MacGregor JT, Wehr CM, Henika PR and Shelby MD (1990). The in vivo erythrocyte micronucleus test: measurement at steady state increases assay efficiency and permits integration with toxicity studies. Fundam. Appl. Toxicol. 14: 513-522.

Ndjakou LB, Vonthron-Senecheau C, Fongang SR, Tantangmo F, et al. (2007). In vitro antiprotozoal activities and cytotoxicity of some selected Cameroonian medicinal plants. J. Ethnopharmacol. 111: 8-12.

Ram VJ and Kumari S (2001). Natural products of plant origin as anticancer agents. Drug News Perspect. 14: 465-482.

Salamone M, Heddle J, Stuart E and Katz M (1980). Towards an improved micronucleus test: studies on 3 model agents, mitomycin C, cyclophosphamide and dimethylbenzanthracene. Mutat. Res. 74: 347-356.

Schmid W (1975). The micronucleus test. Mutat. Res. 31: 9-15.

Singh NP, McCoy MT, Tice RR and Schneider EL (1988). A simple technique for quantitation of low levels of DNA damage in individual cells. Exp. Cell Res. 175: 184-191.

Sokal RR and Rohlf FJ (1995). Biometry. W.H. Freeman, San Francisco.

Speit G and Hartmann A (1999). The Comet Assay (Single-Cell Gel Test). In: Methods in Molecular Biology, Vol. 113, DNA Repair Protocols: Eukaryotic Systems (Henderson DS, ed.). Humana Press Inc., Totowa, 203-212.

Stewart MJ, Moar JJ, Steenkamp P and Kokot M (1999). Findings in fatal cases of poisoning attributed to traditional remedies in South Africa. Forensic Sci. Int. 101: 177-183.

Tice RR, Agurell E, Anderson D, Burlinson B, et al. (2000). Single cell gel/comet assay: guidelines for in vitro and in vivo genetic toxicology testing. Environ. Mol. Mutagen. 35: 206-221.

Veiga-Junior VF, Pinto AC and Maciel MAM (2005). Medicinal plants: safe cure? Quim. Nova 28: 519-528.

WHO (World Health Organization) (2002). Drug Information Herbal Medicines. Vol. 16. World Health Organization, Geneva. Woods PW (1999). Herbal healing. Essence 30: 42-46. 